$\begin{array}{llll}\text { Submitted } & : 28.09 .2020 \\ \text { Accepted: } & : 23.11 .2020 \\ \text { Year } & : \text { December 2020 Volume: } 1 \text { Issue: } 2 \\ \text { DOI } & : 10.47333 / \text { modernizm.2020265885 }\end{array}$

\title{
ESCAPING FROM MODERN CHAOS: BRAVE NEW WORLD
}

Büşra Aslan ${ }^{1}$

\begin{abstract}
Huxley's Brave New World can be seen as the futuristic and dystopic state of the world with the extreme use of technology and the growing power of totalitarian governments in modern period. It demonstrates how this modernity leads human beings to become inhuman. The struggle in the aftermath of the two destructive world wars, the growing technology and the new political and social ideologies result in an enormous change in the world. The crucial changes in modern period caused the state of chaos and depression in society and it led people and mostly the writers to resist these changes and create their own worlds by demonstrating the possible pessimistic future for humanity, which can be called "dystopia". Throughout history, almost every society needed to create a better world because of the problems that they had to face in terms of social, economic and political conditions. In this regard, with Plato's Republic the notion of utopia came into view for the first time and later Sir Thomas More coined the word "utopia" with his book Utopia. Until modern period, utopias were used for criticizing the current situation of society. But in the modern chaotic situation, different kinds of worlds were needed to be created but they were the dystopias which were hopeless and depressed. Dystopias such as 1984, We, and Brave New World should be read as a warning and a political criticism towards the modern notions of politics and technology. As Brave New World has such features as a futuristic and technologically developed state and the clash between nature and science, it can be categorized as a science-fiction novel as well. The aim of this study is to discuss how modern period and modernity affect society and literature in the time being and how Huxley structured his utopian-like dystopia Brave New World by comparing the characteristics of utopia and dystopia.
\end{abstract}

Keywords: Modernism, Utopia, Dystopia, Brave New World.

\section{MODERN KAOSTAN KAÇIŞ: CESUR YENI DÜNYA}

$\ddot{O} \mathbf{z}$

Huxley'nin Cesur Yeni Dünya'sı, teknolojinin aşırı kullanımı ve totaliter hükümetlerin modern dönemde artan gücüyle birlikte, dünyanın fütüristik ve distopik hali olarak görülebilir ve bu modern dönemin, insanları nasıl insanlık dışı bir duruma yönelttiğini gösterir. İki yıkıcı dünya savaşı, gelişen teknoloji ve yeni siyasi ve sosyal ideolojilerin ardından yaşanan mücadele, dünyada muazzam bir değişimle sonuçlandı. Modern dönemdeki önemli değişimler toplumda kaos ve depresyon durumuna yol açarak, insanları ve çoğunlukla yazarları bu değişikliklere direnmeye ve insanlık için "distopya” denebilecek olası karamsar geleceği göstererek kendi dünyalarını yaratmaya yöneltti. Tarih boyunca hemen hemen her toplum, sosyal, ekonomik ve politik açıdan karşılaşmak zorunda kaldığı sorunlar nedeniyle daha iyi bir dünya yaratma ihtiyacı duymuştur. Bu bağlamda, ilk kez Platon'un Devlet'i ile ütopya kavramı gündeme geldi ve daha sonra Sir Thomas More, aynı ismi taşıyan kitabıyla "ütopya" kelimesini ortaya attı. Modern döneme kadar ütopyalar toplumun mevcut durumunu eleştirmek için kullanılıyordu, bu kaotik modern dönemde farklı türden dünyaların yaratılmasına ihtiyaç duyuldu ancak bunlar daha çok umutsuz ve depresif distopyalardı. Öyleyse, 1984, Biz, ve Cesur Yeni Dünya gibi distopyalar, modern dönemin politik, teknolojik ve sosyal kavramlarına bir uyarı ve çoğunlukla politik bir eleştiri olarak okunmalıdır. Cesur Yeni Dünya, distopik ve fütüristik bir roman olmasının yanı sıra doğa ve bilim arasındaki çatışma da dahil olmak üzere teknolojik olarak oldukça gelişmiş durumdaki bir toplumun özelliklerine sahip olduğu için bilimkurgu romanı olarak da kategorize edilebilir. Bu çalışmanın amacı, modern dönem ve modernizmin toplumu ve dönemin edebiyatını nasıl etkilediğini ve Huxley'nin ütopik distopyası Cesur Yeni Dünya'yı nasıl yapılandırdığını ütopya ve distopyanın özelliklerini karşılaştırarak tartışmaktır.

Anahtar Kelimeler: Modernizm, Ütopya, Distopya, Cesur Yeni Dünya.

\footnotetext{
${ }^{1}$ MA in English Language and Literature, Kocaeli University, busraslantr@gmail.com, https://orcid.org/00000002-8658-6748.
} 


\section{Introduction}

Modernism is considered to be a turbulent period regarding the technological innovations, destructive situations in the aftermath of the wars and the new social and political ideologies through the late $19^{\text {th }}$ century and the beginning of the $20^{\text {th }}$ century. The rising of fascism, capitalism, communism, psychological ideas, and social problems heavily affected modern societies, especially in Europe. The destructive effects of the two world wars made a huge difference not only on people's psychology but also on the social and political states in Europe. Societies were dealing with the political oppressions by the totalitarian regimes such as in Germany and Italy. Regarding these issues on the continent, people became unsatisfied with human beings in their hopeless and depressive lives and they wanted to escape. From the early modernism to the late modernism, there was a gloomy atmosphere in the view of people's objectives because of the drastic changes in both society and the world they lived in. While some people were afraid of this chaotic development in technology and of the chaotic situation in the political state, others were just paralyzed by the crucial changes. In political sense, while oppressive and totalitarian powers began to take over the countries in Europe, colonizers began to lose their authority in some of the colonies. Especially, the British empire started to fall apart from its colonies and “modernism's nativist and culturalist turn represents the first part of a decolonizing dialectic in which the tropes and modes of colonial knowledge came home to roost at the end of empire" (Esty 9). So, modern people were dealing with not only the fascist approaches in the political field but also the so-called humanist radical changes which turned societies and people into machines; senseless and emotionless. The combination of these oppressive political activities and the great innovations in technology led people to escape from this chaos and live in some other dimension and some other possible future. Yet this future is darker, and it causes fear. In this regard, modern literature was shaped by these hardships during the late $19^{\text {th }}$ and the $20^{\text {th }}$ centuries.

Artists, writers and poets reflected on the idea of being hopeless, helpless, depressed and oppressed in the time of modern chaos. As a way of escaping from this chaos they produced literary works and there are some examples of modern literature such as Virginia Woolf, George Orwell in the field of novel, Samuel Beckett, Bertolt Brecht in the field of drama and T.S Eliot, Ezra Pound in the field of poetry. Besides these genres, there has always been utopian and dystopian fiction since Ancient Greece to be able to create better possible worlds or ways of life or to criticize the then current status quo. Utopian literature came to life in Plato's The Republic which designed perfectly or maybe even before Plato there were similar ideas about a perfect or better state of living. As a popular genre in the modern period and basically the opposite of the perfect world, dystopia focuses on the worstcase scenarios with the concerns and anxieties about future because of social conflicts and technological improvements. And related to the culture of dystopia, science-fiction is the new genre in that period which is mostly placed in the future and that is why they deal with the advanced stage of technology. Aldous Huxley's Brave New World, published in 1932, can be described as a science fiction novel that is placed in a technologically developed world in the future. Although the system of this new world works perfectly there are some problems in terms of social, psychological, and individual aspects. So, Brave New World can be considered as a perfect utopia to escape from the modern times. This paper aims to indicate the development of utopia, dystopia, and science fiction, and how Huxley's modern novel Brave New World was shaped by their features to escape from the time of chaos.

\section{The Culture of Utopia, Dystopia and Science Fiction}

A map of the world that does not include Utopia is not worth even glancing at, for it leaves out the one country at which Humanity is always landing. And when Humanity lands there, it looks out, and, seeing a better country, sets sail. Progress is the realization of utopias (Wilde 10).

As Oscar Wilde states, utopias help people in the development of the way of living and the progress can help people to find new possible and better worlds. Throughout history, it can be seen the search for a perfect world and "humankind has created fictions of social perfection at least since Plato's The Republic around $375 \mathrm{BC}$ and after that Sir Thomas More gave this thread of intellectual history a name when he called his contribution to it Utopia, Greek for "no place" (Rabkin 7). So, utopias are the unattainable, heaven-like places. As a starting point, The Republic was created to be an example 
for such a kind of world that provides the perfect order in both governing and society as well. Plato's utopia portrays a government of philosophers:

If, in the endless time that has gone by, there has been some necessity for those who are on the peaks of philosophy to take charge of a city, or there even now is such a necessity in some barbaric place somewhere far outside of on range of vision, or will be later, in this case we are ready to do battle for the argument that the regime spoken of has been, is, and will be when this Muse has become master of a city (Plato 179).

So, in his utopic and ideal world view, the philosophers are the perfect option to rule a city. He creates a city which is systematically planned, and each person has a role in this order. Plato's The Republic is a particularly important work in terms of the development of utopian literature. The reason why creating such a kind of possible world may be the need for a better way of living and the criticism of the current situation of the world. As a matter of fact, throughout history people have always needed that kind of inspiration or criticism to make their world more suitable and basically more liveable. In Plato's time, utopian literature was not a genre and the actual name was given by Sir Thomas More with his work Utopia published in 1516 after so many centuries. The meaning of the word utopian comes from Greek words ou 'not' and topos 'place' can be translated as no place. More used this word to show an ideal, heaven-like world which does not have an equivalent in the world as we know it. "More reflects his own ideas through his character Raphael and criticizes his own period about the distortions and inadequacies in the society by creating an ideal island" (Köseoğlu 104). Regarding the time of the book, the inspirations of the Renaissance and humanist ideas can be seen in the book. For instance, the equality for people in society, giving importance to thoughts and ideas, art and reason are the significant ideas of the Renaissance. This utopian island that Sir Thomas More created provides equality for each person and he believed that human beings with their minds and ideals can reach this high level of living conditions:

In Utopia, where every man has a right to everything, they all know that if care is taken to keep the public stores full no private man can want anything; for among them there is no unequal distribution, so that no man is poor, none in necessity, and though no man has anything, yet they are all rich; for what can make a man so rich as to lead a serene and cheerful life, free from anxieties; neither apprehending want himself, nor vexed with the endless complaints of his wife? (More 142-143).

He states that there is no inequality, and every person has the same amount of properties. It is like the idea of socialism in terms of social status and having properties. They have cheerful and peaceful lives and those are their properties. That shows, similar to Plato's thoughts, a society which is perfectly designed for human beings. Yet there is a difference between them; Plato's utopia has class distinction and of course the inequality between women and men while More's utopia has a fully classless society and basically women and men are not that different in terms of working in society. In this regard, utopias reflect a perfect state of society and mostly picture an ideal and heaven-like way of life.

While utopian fiction reflects the worlds such as paradise, dystopia is basically the opposite of the features of utopia. Mostly it is about the horrible future that may happen someday. From the beginning of the modern period, dystopia is one of the most popular genres. The reason why they are popular is that the modern world is shaped by science, and mostly for dystopias science and technology have an important role in terms of futuristic and technologically advanced worlds which they mostly placed. With the help of Enlightenment ideas and through the end of the $19^{\text {th }}$ century "science and technology had become symbols not only of human capability but of human weakness and limitation" as well (Booker 1994, 6). Even if people achieved improvements in the field of science and technology, they were the limitations at the same time.

Dystopian fiction reflects the current problems in a different time period so they should be analysed within political, social, and economical criticism. In this regard, one of the first known examples in the literature of dystopian fiction is Yevgeni Zamyatin's We published in 1921. Although $W e$ is placed in a futuristic world like thousands of years later from modern time, it is about the society in the aftermath of the revolution in Soviet Russia. In the book, Zamyatin "depicts a sterile and stagnant society ruled so thoroughly by scientific and rational principles that its citizens have been 
stripped of any real humanity" (Booker 26). One of the most important features of dystopian fiction is that technological innovations basically turn human beings into machines. For modern people, the future they are to face would probably be a horrible and technologically developed world as they saw the improvement of technology. So much so that human beings have become machines even their names are the numbers just like robots. For instance, D-503 is the main character who is a mathematician and people in this world are stuck in repetitions, eating, working, and sleeping. They are not allowed to be creative or use their imagination which are the characteristics that make us human. Thus, dehumanization, defamiliarization and losing individuality and imagination can be the themes for dystopian literature. People have lost their identities; they are alienated, and they are forced to live like animals without consciousness and in total ignorance.

The reason of writing such novels may be similar to the reasons which are mentioned earlier, to criticize or to warn people and governments for such possible ending, or to show possible good ways to live before losing human nature. In Zamyatin's case the problem was about Soviet Russia and because communism in Russia turned out to be a totalitarian regime and Zamyatin criticized these consequences in his novel. As Mark Preslar states "a free, just, and mature society requires transparency of the motives of authority, of the processes whereby worldview is influenced, and of the ways preferences are shaped" (Preslar 55). In the novel, it has seemed that the complete totalitarian regime which oppresses people and force them to be like one, nonindividual and unconscious. These features are very influential to other important novelists such as Aldous Huxley and George Orwell.

Another particularly important example of dystopian fiction is George Orwell's 1984 published in 1949. It is one of the most popular dystopian works of the modern literature. Without a doubt the novel of Orwell is highly political, and it is shaped by technology as well:
Like both Zamyatin and Huxley, Orwell suggests that certain mechanical applications of technology lend themselves directly to political oppression, even while science itself remains a potentially liberating realm of free thought. Technology is a key tool of the Party in the Oceania of 1984, but the politicization of science and technology in this society has in fact had a suffocating effect on science itself (Booker 70).

Science and technology are the basic units of the dystopian literature and they represent some political problems in a very unusual way which is basically a totalitarian and oppressive power in the future. So, it can be read as a warning or a criticism of the political situations in the time writers wrote their dystopian fiction. Because there were inhuman problems such as the World War II, nuclear bombs, and the rising power of fascist Nazis. It is expected to see their reflections on literature. In the novel 1984 , there is also a totalitarian regime and people are constantly watched by the supreme authority, ruler of the Party, Big Brother. There is this well-known slogan "Big Brother is watching you" which makes all the people feel uncomfortable and even paranoid. Similar to $W e$, here, people are forced to be one stereotype to systemize and rule them fully. Other slogans in the novel can summarize the oppressive world view and the crucial way of manipulation of the Party:

\section{WAR IS PEACE \\ FREEDOM IS SLAVERY \\ IGNORANCE IS STRENGTH (Orwell 6).}

To control people and make them as one individual, the authority constantly tries to manipulate them and convince them to believe that freedom is not something good but in fact, it is slavery or being ignorant equals to being strong in this sense. So, it is a constructed dystopian world which is very systematic and oppressed by strict rules.

Lastly, the genre of science fiction, just like dystopia, is causally related to the development of technology and science. As an example, Mary Shelley's Frankenstein (1818) is one of the first science fiction novels which deals with some conflicts between nature and science. To understand this kind of fiction and its features, focus should be on the concepts of utopian and dystopian literature as a way of escaping or criticising the current situation in the time being. As they basically picture the possible universes or sometimes governments and cities including their own characteristics but with different 
approaches. Comparing the dystopian and the utopian literature, they both have constructed systems for society, but the differences are the freedom of people and the controlling powers over society in those worlds. For example, in dystopian fiction the authority includes the oppressors and people are mostly forced to be loyal. On the other hand, in utopian fictions people in society can achieve real freedom and satisfaction. Also, in most of the dystopian worlds the focus is on the development of technology and they are basically placed in a possible future. That is why the development of technology is the milestone of dystopian literature. Similar to dystopian fiction, science fiction also has the theme of the clash between science and nature as in Frankenstein and Brave New World because of the destruction of advanced technology which eliminates the features of humanity. Additionally, Herbert George Wells and George Orwell produced novels that can be regarded as science fiction which has the themes of the conflicts between the rules of nature and science with human cruelty. All these works in the $20^{\text {th }}$ century are "to establish the terms of the modern genre of dystopian fiction, which itself exerted a strong influence on the rest of science fiction" (Booker 3).

So, in modern chaos, most of the writers tended to escape this depression and hopeless state of mind which are the consequences of the political, economic, and social hardships at that time. Not only to escape but also to criticize and warn the reader and maybe even governments and countries by creating such dystopic worlds and to show what people could face in the future. One of the best examples of these kinds of dystopian worlds, Brave New World clearly shows how humanity can be lost with the development of technology and science and it is the way that Huxley tried to escape from the chaos in his time.

\section{Brave New World: A Modern Parody of Utopia}

As mentioned earlier, Brave New World is both a utopian and a dystopian work because the system works perfectly, and people seem happy and satisfied with their lives. However later on it is revealed that this brave new world is actually a dystopia because of the constant controlling powers on people through technology and science. Considering the systematic order and prosperity of people in society, it seems like a utopian world but actually it is a parodical way to take the attention. In fact, the parodical utopian world of Huxley hides the reality behind this perfect system. The reality is making people ignorant, seeing them as mass production and these are the features of a dystopian world. In this regard, this new world can be seen as a modern parody of utopia which turns out to be a dystopia.

It takes place in World State in the year AF 632, After Ford stands for Henry Ford who is a god-like figure in this universe. As technology has a crucial influence on both dystopian and science fiction, for Huxley the first ford car was very influential because Henry Ford's "assembly-line process produced affordable cars, which Huxley and Maria to buy their first car when they moved to Italy" and he even named his messiah character after him (Reiff 42). In this regard, technology has its mission to determine the new brave world. The novel can be read as both dystopic work and a science fiction as well. In terms of modern dystopian literature, the novel has such themes and features along with the genre. According to the title, this new world of Huxley is so brave in terms of technology that people are controlled by the technological features and this is the point where the novel becomes a dystopia. The novel poses an important question: would people rather be happy and ignorant, or they want to be completely free? Considering the time of the novel was written, there are some conflicts in the field of politics in society such as the rising power of fascist governments in Europe and the unsuccessful communist attempts in Russia. All these political, economic, and social events in the modern period had an influence on Huxley's futuristic novel.

The novel opens with the Director's information about how they create the system in their socalled utopic world. People are created in some tubes by way of fertilization of eggs and they even can get ninety-six identical from one egg. It is stated in the novel, how reproduction is replaced by technology that is vital to all living things. In this new world, being pregnant is actually something to be ashamed of. As clearly seen in the novel people are alienated from human nature and the emotional bonds like family and motherhood (Huxley 3-4). Also, the novel focuses on the characters who are not like the rest of the society, Bernard, Helmholtz, John the Savage and Mustapha Mond. In the perfectly working system there is a clear-cut caste system and the most important characters are from the highest classes. For instance, Bernard is a psychologist and he and his friend Helmholtz are like 
outsiders to the world because they want to feel something, they are close to the world in which emotions are praised, and not to the futuristic and the technologically developed new world. Another especially important character John the Savage is born in the Savage Reservation in New Mexico and later it is revealed that John is the son of Mustapha Mond who is one of the controllers in this system. And there are women characters Lenina and Linda. Through these characters, their personalities and their actions, Huxley tries to give his ideas about the anxieties about the future, the problems of society and the possible clash between nature and technology.

The totalitarian governments and oppressive powers are the important characteristics of dystopian literature. In Orwell's 1984 people are aggressive and violent because they lack of freedom and satisfaction in society but in Brave New World people do not have to be free because they are satisfied with the way of their lives and they are even tranquilised. Soma is a drug to be used for people in their everyday lives. Huxley defines this drug as dangerous in his writing about the novel "Brave New World Revisited":

The systematic drugging of individuals for the benefit of the State (and incidentally, of course, for their own delight) was a main plank in the policy of the World Controllers. The daily soma ration was an insurance against personal maladjustment, social unrest and the spread of subversive ideas. Religion, Karl Marx declared, is the opium of the people. In the Brave New World this situation was reversed. Opium, or rather soma, was the people's religion. Like religion, the drug had power to console and compensate, it called up visions of another, better world, it offered hope, strengthened faith and promoted charity (Huxley 1958).

Using Soma makes people stay under control even if it seems to be for their own sakes. Being emotionless may be the worst thing for humanity and Huxley warns us about the policy of domination. In the novel, soma is a very good tool to make people ignorant and blind to the problems in the World State; "there is always soma, delicious soma, half a gramme for a half-holiday, a gramme for a weekend, two grammes for a trip to the gorgeous East, three for a dark eternity on the moon." (Huxley 57) When John the Savage comes to London and encounters with the idea of being tranquilised by a drug, he thinks this soma is dangerous and it limits the freedom of people and even it makes people like slaves. "But do you like being slaves? Do you like being babies? Yes, babies. Mewling and puking. Don't you want to be free and men? Don't you even understand what manhood and freedom are?" (Huxley 236) As a real outsider to this system, John the Savage is actually the one who is more civilized here in the so-called perfect civilization. He may symbolize the last stand against technology and science that tear off the roots of humanity. The system offers people hope and peace but actually people are just tranquilized by soma and they are forced to be like machines. The reality is different from the appearance of this new world. In this regard, one of the main problems of dystopian fiction and science fiction is being a stereotype figure or losing individual and human features. Just as Orwell's dystopia 1984, Brave New World also “depicts a technologically advanced, minutely organized world state whose inhabitants are programmed to eliminate individual differences in order to enforce a stable society" (Sion 127). People in these dystopic worlds are alienated from themselves, each other and even their humanities, they are just like robots who do the same things every day without any passion or emotion:

Tall and rather thin but upright, the Director advanced into the room. He had a long chin and big rather prominent teeth, just covered, when he was not talking, by his full, floridly curved lips. Old, young? Thirty? Fifty? Fifty-five? It was hard to say. And anyhow the question didn't arise; in this year of stability, A. F. 632, it didn't occur to you to ask it (Huxley 3).

Here, there is nothing important in terms of one's characteristics, age, or physical appearance because people are indeed some tools for greater powers in such totalitarian worlds. There is a community rather than individuality in this world and the World State's motto is "COMMUNITY, IDENTITY, STABILITY" which summarizes the hidden oppression on people in the brave new world of them (Huxley 1). Even though the World State tries to spread the idea of being united and being one there is a crucial class distinction in this universe. Again, the parodical approach comes to the fore, this perfectly designed system actually discriminates people and even children have to practice the class consciousness: 


\begin{abstract}
Alpha children wear grey. They work much harder than we do, because they're so frightfully clever. I'm really awfully glad I'm a Beta, because I don't work so hard. And then we are much better than the Gammas and Deltas. Gammas are stupid. They all wear green, and Delta children wear khaki. Oh no, I don't want to play with Delta children. And Epsilons are still worse. They're too stupid to be able ... (Huxley 29).
\end{abstract}

There is a caste system in this brave new world and each class must wear different colours to be known by others. There are the major classes Alpha, Beta, Gamma, Delta, and Epsilon. Deltas are the non-intellectual class, and they are raised by their caste system. They are forced to learn and dislike the nature and the source of knowledge, books:

Books and loud noises, flowers and electric shocks already in the infant mind these couples were compromisingly linked; and after two hundred repetitions of the same or a similar lesson would be wedded indissolubly. What man has joined, nature is powerless to put asunder (Huxley 22).

With real physical harm children have to learn instinctively that nature and books are not good for them, especially Delta and Epsilon children are basically raised for working in the sewage. On the other hand, Alphas and Betas unlike other classes are the highest castes in society so they are not working in dirty jobs, but they mainly work in decent and intellectual jobs. As it can be indicated here, all people are born into a designed world, everyone has a part in society. As Olander states each child is subjected to several years of psychological conditioning reminiscent of Plato's "necessary lies" and Pavlov's classical conditioning experiments with dogs (Olander 95). So, they are prepared for their designed lives in the perfect system that every one of them has a mission as they are like tools. As science is used to produce people, mass production is one of the main problems in this totalitarian world. As mentioned before, people are produced like products:

One egg, one embryo, one adult normality. But a bokanovskified egg will bud, will proliferate, will divide. From eight to ninety-six buds, and every bud will grow into a perfectly formed embryo, and every embryo into a full-sized adult. Making ninetysix human beings grow where only one grew before. Progress (Huxley 4-5).

It is called Bokanovsky's Process and it turns people into machines or some mass products. Just like Henry Ford developed mass production of cars, in the World State, people are created by genetic engineering like they are such kinds of products as cars. So, thanks to science and technology people have lost their nature and they are alienated from their own essence. It is quite similar to the situation of modern people. They have also lost their nature, meaning in life because of all the politics, economic crisis and social problems. Even if the novel is placed in a futuristic world one can see the similarities between the modern period's problems and the problems of possible future. So, Huxley's Brave New World is "a scientific dystopia with a considerable overlay of political and social exploration" and it certainly implies that "freed from the mind-crushing restrictions of an inhuman, technological, totalitarian society, the human spirit would grow again" (Rabkin 29). There is always hope for a better world, even in the most totalitarian and oppressive systems or technologically developed societies in their inhuman ways.

Another important issue to mention is that the use of the Savage Reservation is the symbol of the history of humanity. There is a clash between nature and technology in the novel and while the Savage Reservation stands for nature, the World State symbolizes the extreme use of technology. Without a doubt, people are completely different in these two different areas:

In Brave New World, Huxley shows that any society that has set happiness and material well-being as its goals must, for the sake of stability, deliberately cultivate mediocrity and perpetual adolescence in all but a tiny portion of its numbers. If, on the other hand, it wants to make its members fully human, individual, and independent, it must abandon the economic, political, and social structures that impose conformity - in a word, it must revert to primitivism, with all of the attendant disease, intolerance, and ignorance. In the novel, the only two choices are the brave new world and the savage reservation; man has the choice, Huxley says in his preface, between insanity on the one hand and lunacy on the other (Bloom 19). 
This distinction of two places is reflected by the characters, John the Savage is the more primitive one and Bernard, Lenina, and Mond represent the developed inhuman side. These characters undergo some problems, for example, John is found by Bernard and Lenina, and the truth that John is the son of Mustapha Mond appeared. This information makes people in the World State irritated because being born from a mother is quite unusual for them and it is the real decadence in the state. When John proposes to Lenina, their different cultural backgrounds caused a conflict between them because there are no real emotions here and marriage is also prohibited. John, on the contrary, is from "primitive culture", and they give importance to monogamy and marriage so the sexual offers from Lenina make him think that Lenina is a "whore" (Huxley 214). After encountering each other none of these characters could find a way in the middle because their backgrounds are so different from each other. Mustapha Mond explains the differences between the old living way and the brave new way:

\begin{abstract}
Mother, monogamy, romance. High spurts the fountain; fierce and foamy the wild jet. The urge has but a single outlet. My love, my baby. No wonder these poor premoderns were mad and wicked and miserable. Their world didn't allow them to take things easily, didn't allow them to be sane, virtuous, happy. What with mothers and lovers, what with the prohibitions they were not conditioned to obey, what with the temptations and the lonely remorses, what with all the diseases and the endless isolating pain, what with the uncertainties and the poverty-they were forced to feel strongly. And feeling strongly (and strongly, what was more, in solitude, in hopelessly individual isolation), how could they be stable (Huxley 44).
\end{abstract}

What is indicated here is that the Indians in the Savage Reservation are considered as miserable by the modern ones like Mond. As a matter of fact, they have so many difficulties in their way of living such as diseases and poverty, but they can feel free or passionate about something. For example, John is fond of Shakespeare which is a symbol of feelings in the novel. It is restricted in the World State because literature can expose the emotions of people and it may lead to instability in society which is not something the greater powers desire; so, they do not "encourage them to indulge in any solitary amusements." (Huxley 179) Another difference is that for the people in the World State sexuality is used for distraction not for procreation. All the emotional bonds are restricted by the controllers, but sexual intercourse seems to have a meditative mission and even children can involve erotic games; "two children, a little boy of about seven and a little girl who might have been a year older, were playing, very gravely and with all the focused attention of scientists intent on a labour of discovery, a rudimentary sexual game" (Huxley 32). It is quite ironic that they disgust the idea of being a family, mother and child relationship yet they can have sexual games. All the things that cause emotion such as family, marriage, monogamy, literature and finally religion are despised. Because they have to be controlled by the system, the totalitarian power, which discriminates and ignores their human emotions and traditions. This perfect system continues if only people are tranquilized by soma to feel happy and ignorant.

In Huxley's brave new world religion is considered as dangerous as well but there is an important religious kind of figure: Henry Ford. He is a symbolic figure in the book because of the main feature of the World State is the concept of mass production. The controllers of the state think that religion should also be abandoned, but actually it is changed from "Our Lord" to "Our Ford". To make religion related to technology Ford has become Jesus Christ in the brave new world and that is the main idea in this modern world of Huxley. In the future, even religion is about technology and it is the end that people will end up with. Huxley tries to show that the capitalist, oppressive and totalitarian systems create a conflict between nature and technology and this conflict may end the existence of humanity in this world. And it is achieved with science fiction because the novel mainly focuses on technology and science. He preferred to create a futuristic world to criticize and warn people because there were also totalitarian rulers in his own time. Taking this into account, it is clear to see that Huxley's utopian-looking dystopia is absolutely a mirror to the modern world in terms of technology, social and political issues. The message should be taken into consideration which is the importance of the nature of human beings and how they once lived in harmony with nature, otherwise people may lose their humanity and end up by saying that "there was a thing called the soul and a thing called immortality" once but not anymore (Huxley 54). 


\section{Conclusion}

As a conclusion, Brave New World of Huxley is affected by the important events in his time like every other literary work. The problems of the modern period such as the effects of two world wars, the rising ideas in politics such as fascism, communism and capitalism, and social difficulties led societies to depression and chaos. Most importantly, political struggles later become an oppressive, totalitarian government and the development in the field of science and technology have an enormous impact on both people's lives and implicitly on literature. Throughout history writers and literature take their material from the world around them. They create their own worlds in their writings either to criticize or to make better the actual one. These better or ideal worlds of writers are named utopia they are mostly about the political and social structure. As the meaning of utopia suggests no place in Greek, it is considered as perfect systems or governments. The first utopian example is Plato's The Republic, and he creates a perfect governor system in his work. Later, with the humanist and idealist ideas in Renaissance, utopias gain power. In fact, the name utopia is given by Sir Thomas More with his work Utopia in 1516. In his book he creates an island where everyone in society is happy and equal. It is important to remember that the social and political problems have real influences on these works, and one should pay attention to the message that these works try to give.

While utopias represent the perfect and ideal way of living, in the modern period and with its dark and depressive atmosphere the idea of anti-utopia started to be shaped. Dystopias stood for the horrible future in front of humanity and all the destructiveness of modernity makes writers so pessimistic and some of them create these dystopias as an example of the human future. In this regard, Zamyatin's We, Orwell's 1984, and Huxley's Brave New World are three of the most important examples. They all reflect the most horrible totalitarian powers and the extreme consequences of the development of technology. Yet Huxley's dystopia seems like a utopia at the beginning because people are happy and satisfied and the system works perfectly. But in fact, people are restricted from anything related to their human nature such as emotions, birth, family relations, love, marriage, art, and literature as well. They are forced to live like machines, and they are ignorant because of limited education and they are literally tranquilized by some drugs named Soma. Huxley clearly criticizes the totalitarian and oppressive powers in governments and the irrevocable consequences of the development of technology. Because the novel deals with science and technology in a futuristic world it can be considered as a science fiction which is a genre deals with futuristic and technological fiction and the clash between nature and science. Even so, the novel is a criticism of the political and social problems which result in chaos and depression through the characters, their cultures, their way of living and their actions. All in all, Huxley creates a dystopic and futuristic science fiction, a brave new world concentrating on the technological innovations, as a way of escaping from the modern chaos and to warn people for the possible horrors of a future in which we lose our humanity and nature.

\section{WORKS CITED}

Bloom, Harold. Aldous Huxley, New Edition. Bloom's Literary Criticism Infobase Publishing, 2010.

Booker, M. Keith. Historical Dictionary of Science Fiction in Literature. The Rowman \& Littlefield Publishing Group, 2015.

Booker, M. Keith. The Dystopian Impulse in Modern Literature: Fiction as Social Criticism. Greenwood Press Westport, 1994.

Esty, Jed. A Shrinking Island: Modernism and National Culture in England. Princeton University Press, 2004.

Huxley, Aldous. A Brave New World. Coradella Collegiate Bookshelf Ed. Web. 2004.

Huxley, Aldous. “A Brave New World Revisited” Huxley.net Web. 1958.

Köseoğlu, Berna. "Rönesans Dönemi Ütopyaları", Ütopyada Edebiyat Edebiyatta Ütopya. Ed. by Metin Toprak and Güvenç Şar. Umuttepe Yayınları, 2019.

More, Thomas. Utopia. 1516. Planetbook Web.

Orwell, George. 1984. 1949. Planetbook Web. 
Plato. The Republic. trans. by Allan Bloom. Basic Books, 1991.

Preslar, R. Mark. "Yevgeny Zamyatin's 'We': Forbidden Knowledge and Coercion in Utopia." Soundings: An Interdisciplinary Journal, vol. 91, no. 1/2, 2008.

Rabkin, Eric S. No Place Else: Explorations in Utopian and Dystopian Fiction Alternatives. Ed. by Eric S. Rabkin, Martin H. Greenberg, Joseph D. Olander. Southern Illinois University Press, 1983.

Reiff, Raychel Haugrud. Aldous Huxley: Brave New World. Marshall Cavendish Benchmark, 2010.

Sion, Ronald T. Aldous Huxley and the Search for Meaning. McFarland \& Company, Inc., 2010.

Wilde, Oscar. "The Soul of Men”. The Project Gutenberg eBook. Online Release Date, 2014.

Zamyatin, Yevgeny. We. trans. by Clarence Brown. Penguin, 1993. 